\title{
The Analysis of The Impact of Accounting Information System on The Effectiveness of Internal Control
}

\author{
Mas Said Resna Hadiwijaya ${ }^{1}$, Agung Praptapa ${ }^{2}$, Icuk Rangga Bawono ${ }^{3^{*}}$ \\ *Jenderal Soedirman University Purwokerto \\ Economic and Bussiness Faculty \\ Profesor DR. HR Boenyamin Street No.708, North Purwokerto, Banyumas 53122 \\ Corresponding Author: cukycutes@yahoo.com
}

\begin{abstract}
this research aims to analyze the influence of accounting information system on the effectiveness of internal control at pt. langen kridha pratyangga sumedang. object of this research are people/human resources, procedures and instructions, data, software, information technology, and internal control in pt. langen kridha pratyangga sumedang. the implementation of this research used quantitative method, by using purposive sampling technique. the sample size was 70 persons employee whose listed in pt. langen kridha pratyangga. . questionnaire and interview are used as research instrument to gather data for survey tecnique that use in this research. multiple linear regression was used as the method of analysis. the result of this research show procedures and instructions, data, software, and information technology infrastructure has significant and positive influence on the effectiveness of internal control. meanwhile the people/human resources have no influence on the effectiveness of internal control. in conclution, pt. langen kridha pratyangga sumedang must pay more attention to procedures and instructions, data, software, and information technology infrastructure in order to increasing effectiviness of internal control.
\end{abstract}

keywords: people/human resources, procedures and instructions, data, software, information technology infrastructure, internal control

\begin{abstract}
Abstrak
Penelitian ini bertujuan untuk menganalisis pengaruh sistem informasi akuntansi terhadap efektivitas pengendalian internal pada PT. Langen Kridha Pratyangga Sumedang. Objek penelitian ini individu/sumber daya manusia, prosedur dan instruksi, data, perangkat lunak, infrastruktur teknologi informasi dan efektivitas pengendalian internal. Implementasi penelitian ini menggunakan metode kuantitatif, dengan menggunakan teknik purposive sampling. Jumlah sampel adalah 70 orang karyawan yang terdaftar di PT. Langen Kridha Pratyangga. Kuesioner dan wawancara digunakan sebagai instrumen penelitian untuk mengumpulkan data dalam teknik survei yang digunakan dalam penelitian ini. Regresi linier berganda digunakan sebagai metode analisis. Hasil penelitian ini menunjukkan prosedur dan instruksi, data, perangkat lunak, dan infrastruktur teknologi informasi memiliki pengaruh yang signifikan dan positif terhadap efektivitas pengendalian internal. Sementara itu individu/sumber daya manusia tidak memiliki pengaruh terhadap efektivitas pengendalian internal. Kesimpulannya, PT. Langen Kridha Pratyangga Sumedang harus lebih memperhatikan prosedur dan instruksi, data, perangkat lunak, dan infrastruktur teknologi informasi untuk meningkatkan efektivitas pengendalian internal.
\end{abstract}

Kata Kunci: individu/sumber daya manusia, prosedur dan instruksi, data, perangkat lunak, infrastruktur teknologi informasi, pengendalian internal 


\section{Introduction}

The Rapid changes in the field of information technology, economic, social, culture and politic influence the conditions of competition in the business world that is increasingly growing fast. It directly affects the competition among companies, so they need to adjust continually their information system to maintain fit with the real world [26]. Productivity is one of the important aspects that remain could be enhanced through competition. It happens because the information makes the data processed to be useful, so it can be relied upon the right of decision making to its users.

Globalization influences also has triggered a business and economics to perform various actions in order to keep its business effectively and efficiently works, so that no competition was thrown from its business. To keep competing, then the businessman should be able to perform various transformation activities of its economy activity to be effective and efficient as possible. Advances and utilization technologies, especially information and communication technologies on every activity and process of creating new perspective on the economic aspects of people, procedures and instructions, data, software, and information technology infrastructure. By applying information and communication technology, it is expected to help management collects the data, analyzes the data and produces information, so it directly affects the effectiveness and efficiency of management decision making through action based information generated.

The need for the existence of an adequate information system almost happens in various types of businesses. Information system is a set of formal procedures for collecting the data to be processed into information and distributed to the users [13]. One type of information systems is the accounting information systems (AIS). AIS provides the information needed to help managers plan, control resources, evaluate performance and make decisions in most effective and efficient way.

AIS can be called formal vehicle for the operational processing of accounting data and related decision support activities. It gathers financial and non financial data to distribute either inside and outside party that has necessary bussiness [28].

AIS also contained control element, so it can affects the function of management in performing control within internal control system infrastructure. The function of accounting information system plays almost all over control of the company conducted [30]. The implementation of AIS should be handled carefully in order to avoid misappropriation, fraud, and intentional or a mistake, whether it is unintentional in organization. So, information that provide by AIS has to reliable, accurate, trustworthy to users (or management on this content) in a time frame, in a form, and relevant for them $[3,15]$.

In the early year of 2014, Indonesian Supreme Audit Institution (BPK RI) found 10.996 cases caused by low quality of internal control. BPK RI explains that all of the total findings as much as 3,452 cases worth for IDR 9.24 trillion which has the financial impact that resulted in losses, the potential harm, which affects directly on domestic revenue. The details that prove SPI cases are 1.840 cases worth for Rp1.78 trillion. Then, the potential losses of the country recorded are 586 cases worth for IDR 4.85 trillion [2]. By implementing internal control system in the company, it is expected that company asset can be protected from physical damage and fraud. In addition, it also provides the data accuracy and avoids from good record-keeping errors intentional as well as unintentional.

IT skills of human resources can provide an important competency that ensures organization's AIS remains aligned with rapid changing of business environment [28]. This makes organization has obligation to recruit and train their human resources for ensuring maintain fit to AIS with the organization's qualification. The important competency that must human resources provide is ability to leverage AIS in unique ways [26]. But beforehend, human resource required to have a level of accounting expertise or being able to continue learning accounting.

While organization try to design effective and efficient work standard, prosedure and instructions in AIS may play important role on the effectiveness of internal control. This include providing team work, chain of command with information, management cycle, and decentralization. But there's a note to provide procedure and instruction work on effectiviness of internal control. It must based on employee capability. A firms with more employeefriendly policies are less likely to incur material weaknesses in internal control [11].

Data quality has become a crucial matter for the success of implementing AIS. This neediness arises for quality management of data, as data processing has shifted from the role of operations support to a major operation in itself [33]. Companies have to provide great data quality to empower monitoring and testing information of AIS [3].

Developments of IT these recent years also greatly help accounting in demonstrating functional efficiency with enhanced accounting tasks routine and closing accounts process [8]. One factor provide these efficiency is software that can make ease users 
to do their task. So, software may effect on effectiveness internal control of company. The problem that often arise in the use of accounting software is not compatible with computer systems with business processes and organization information required [16]. A mismatch between software applications with business processes can cause significant problems for users.

The role of information technology infrastructure may not be forgotten. Information technology infrastructure which is often called hardware. According [17] information is a product of AIS. Information technology infrastructure plays a role in providing useful information for decision makers within the organization including reporting to support the decision making process effectively.

PT. Langen Kridha Pratyangga has implemented internal control system with optimized cost control and internal audit. The implementation of the internal auditing function is carried out to supervise and check the other functions in the company, so that system procedures and regulations companies may perform well. The similar research has already been done by some earlier researchers such [20]found that AIS show a very strong influence on the internal control effectiveness of sales at the company's garment in Tanjungpinang. Other research such $[3,12,15]$ that show overall AIS support effectiviness of internal control. But there's subvariable in AIS that not support efectiviness of internal control such accuracy reports and principal's education. So, there's a chance another factor affecting the effectiveness of the implementation on the internal control.

Based on results gap of previous research and discussion about research background that already explained and there's a probability another factors in AIS that can affect company internal control. So, this research aims to analyze impact of accounting information system on the effectiveness of internal control.

\section{Literature Review}

\section{Theory of Reasoned Action (TRA)}

One kind of improvement over Information Integration theory was developed by [1] called The Theory of Reasoned Action (TRA). There are two important points that change. First, Reasoned Actions add another component in the process of persuasion that is behavioral intention. Rather than try on predict attitudes, TRA explicitly concerned with behavior. Therefore, TRA predicts behavioral intention that being interpreted as compromise between stopping at attitude predictions and actually predicting behavior. Because it separates behavioral intention between behavior, TRA also discusses other factors that limit the influence of behavioral intention on behavior.
Second, TRA uses two elements to predict behavioral intent that's attitudes and norms (expectations of other people). Whenever attitudes lead someone to do something but the relevant norms to suggest we should do another thing, those factors can influence someone's behavioral intent.

TRA explains that people will consider cognitive aspect and norms towards their attitudes. The organizational structure is perceived as a family and friends who are all of their attitudes will reflect which family and friends around. Then, data is kind of information that spread by environment. The judgmental of an environment will be considered by individual to act. While house is described as infrastructure information technology or hardware. An office owned by employees to always learn in terms of achieving human quality standard. People will always attract to get a reward and also being recognized by their environments. These kinds of components will also to achieved harmony and integration to get effectiveness, especially in internal control.

\section{System}

[21] defined a system as a group of elements that are integrated with the same intent to achieve a purpose. [17] defines a system as a network of procedures that are interconnected, gathered together to perform an activity or complete a certain goal. Procedure defined as a clerical job sequence, it involved several people or more, arranged to ensure the existence of a corporate transactions[6]. The system approach is a set of elements or components or subsystem in a common. It means, that a single system can be composed to several subsystem or parts of system.

A system should support decision making of each level management of the organization. According to [17], the characteristics of a system define, "A system has a characteristic or specific property, which has components, boundary, environments, interfaces, input, output, process and objectives or goals".

There are classifications in a system, according to [18], system can be classified by closed system, highly closed system, and open system. Closed system is There is no relationship with external parties, so that the system does not have an influence on and influenced by an environment that is outside the boundaries of the system. Highly closed system is kind of system has a communicator that connects the system with its environment and controlling the environmental impact of the processes carried out by the system. open system is also acquired disorders, uncontrolled inputs that will influence the processes in the system. A well designed system can be minimized this disorder, with anticipation to the possibility of the emergence 
of disturbances of the environment and then creates the process and ways to cope with the disorder.

\section{Information}

According to [18] information is defined as data that have been organized, and have had usability and benefit. Information is defined as a system composed of individuals and computers that processes or interprets information[7]. The characteristics and types of information will be related to the information needs on the levels of management. It has function to transform data into information that is valuable information to all levels of management. The terms are additionally sometimes utilized in more restricted senses to ask only the software wont to run a computerized database or to ask only a computing system. To provide useful output for assisting managers and other users, information must collect data and convert them into information that possesses important qualities. [12] defined criteria of quality of information as useful information is one that have several characteristic such as relevance, accuracy, timeliness, summarization, and completeness.

\section{Accounting Information System}

[27] defined accounting information system as tracking accounting activity in conjunction with information technology resources based on computer-based method. [13] defined the accounting information system: "Accounting information system consists of three main subsystems: (1) transaction processing system, which supports the business operations on daily basis with several documents and messages to users through the organization; (2) a reporting system ledgers/finance (financial reporting system/general ledger), that produces traditional financial reports; and (3) the management reporting system, which provides internal management with special purpose financial reports and information necessary for decision making".

The main purpose of preparing accounting information system for an organization of companies according to [19] talk about improving quality of information, enhancing the internal control system, and reducing administration cost. AIS in general consist of five main parts: people, data, procedures and instructions, information technology infrastructure, software, and internal controls [27].

\section{Effectiveness of Internal Control}

A process to provide reasonable assurance to achieving objectives efficiency and effectiveness of operations, reliability of reporting, and compliance with applicable regulations and laws is a definition of internal control. Meanwhile [27] defines internal control as the organization plan and the business methods used as safeguarding company assets, promote and improve operational efficiency, provide accurate and reliable information, and encourage compliance to prescribed managerial policies. Internal controls include all the procedures and adopted by the management of an organization to help in reaching management's goals [3].

An internal control system is an amalgamation of several policy and procedure that a company implements to ensure that each of its goals is achieved. The Committee of Sponsoring Organizations of the Treadway Commission (COSO) recognizes five essential components to this system which include control activities, communication and monitoring, gather information, risk assessment, and control environment. The reason for management to design an effective internal control system is so as to achieve reliability of financial statements, effectiveness and efficiency of a company's operations, and compliance with laws and regulations [22].

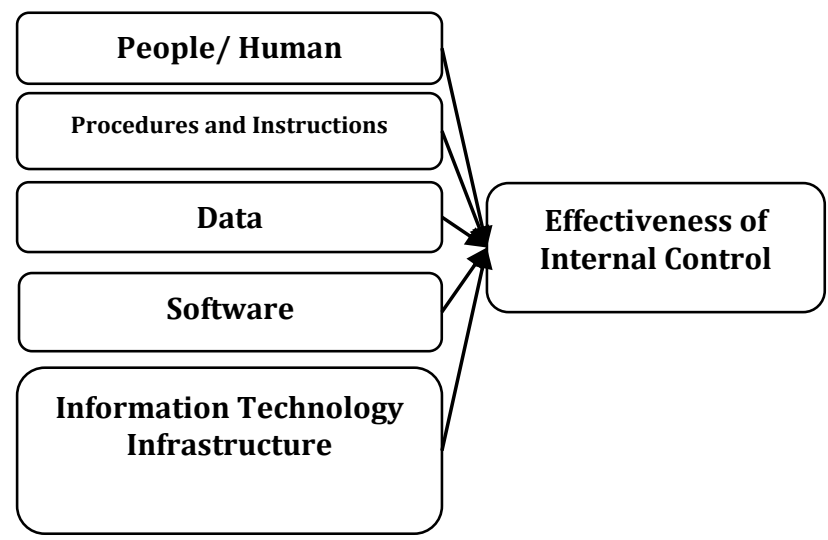

Fig. 1 Conceptual Framework

From conceptual framework that shows in Fig. 1, can be conclude hypothesis on this researh:

TRA which explains intention is influenced by human activity, whereas someone intention is influenced by subjective norms and attitudes. Subjective norm is influenced by confidence in the opinions of others as well as motivation to keep the opinion. Attitude is influenced by confidence in the results of the actions before. Simply, this theory says that someone will do an action when he looked it is positive and if he believe that other people want him to do it [4]. Personnel policy participation influences the company's ability to hire employees who are quite capable to accomplish company goals. This policy outlines include companies hire, train, evaluate, promote, and provide rewards on employees. Managing human resources is a crucial matter for companies, especially for companies with a large number of employees [5]. In larger companies, it is not easy to maintain an accurate view of the employee's competences. Through 
proper mapping competency of human resources, it will provide internal control effectiviness through ability and honesty of employees. By put qualified and competent human resources in right place, needed to do better of applying AIS due prevent inefficiencies do reach organization goal [23]. This argument also supported by [14].

$\mathbf{H}_{1}$ : The people/human resources have influence on the effectiveness internal control PT. Langen Kridha Pratyangga Sumedang.

Implementation of procedures and instructions in the company consider the TRA attitude towards behavior. Attitude is a function of the belief about the consequences the behavior or beliefs, normative perception against the consequences of a behavior and judgment against such behavior. The attitude factor is main point of changing behavior indicated by a changing in attitude of a person to face something. The changing in attitude may take the form of acceptance, and also rejection [4]. The quality of the internal control is considered effective if each function or part that authorizes the activity of the company. Separation job and functions are required to reduce the possibility of confusion and irregularities. This separation such giving authorization for selected person [11]. [20] also argued there's a significant and positive influence of the quality of the procedures and instructions on the effectiveness of the internal control system.

H2: The procedures and instructions have influence on the effectiveness internal control PT. Langen Kridha Pratyangga Sumedang.

TRA provides a handle to analyze the component behavior in operational items. The target is to predict and understand behaviors that can be observed directly and below control of a person. It means that the behavior of the target must be selected and identified clearly. These demands require consideration regarding the action, target, context, and the difference of time as well as its own model components including intention, attitudes, subjective norms, and beliefs. Important concept in TRA is focused on attention (salience). Meant, before developing effective interventions, firstly determine the results and reference groups that are important to the behavior of the population. Thus, it should be noted the values and norms of social group investigated (the important thing is not the culture itself, but the way culture influences the attitude, purpose, and behavior) [4]. Data quality has become a crucial matter for the success of implementing AIS. This neediness arises for quality management of data, as data processing has shifted from the role of operations support to a major operation in itself [33]. Companies have to provide great data quality to empower monitoring and testing information of AIS [3].

$\mathbf{H}_{3}$ : The data have influence on the effectiveness internal control PT. Langen Kridha Pratyangga Sumedang.

The implementation of applications and software in the company is related with the importance of the norms advanced in the TRA, in this case the software used is capable of protecting the norm in society, the influence of socio-cultural factors prevailing in the society in which one lives. Socio-cultural elements also can bring someone to adhere to or abandon a behavior [4]. Developments of IT these recent years also greatly help accounting in demonstrating functional efficiency with enhanced accounting tasks routine and closing accounts process [8]. One factor provide these efficiency is software that can make ease users to do their task. So, software may effect on effectiveness internal control of company. The problem that often arise in the use of accounting software is not compatible with computer systems with business processes and organization information required [16]. A mismatch between software applications with business processes can cause significant problems for users implementing AIS for internal control effeciency. This argument also support by [8] and [15] current technologies in the enterprise seem to be going through major changes have implement software to simplify the control process.

H4: The software has influence on the effectiveness internal control PT. Langen Kridha Pratyangga Sumedang.

Subjective norms in the TRA noted in the utilization of information technology are related to the environment and co-workers. Subjective norm or norms embrace a person (family). Urge family members, including a nearby comrade is influence a person to receive particular behaviors, followed by suggestions, advice and motivation from family or friends. The ability of a family member or friend nearby affect an individual to behave like they expect is obtained from experience, knowledge and judgment of the individual against a particular behaviors and beliefs to see suggested other people behave [4]. According [17] information is a product of AIS. Information technology infrastructure plays a role in providing useful information for decision makers within the organization including reporting to support the decision making process effectively. This argument also supported by [34].

H5: The information technology infrastructure has influence on the effectiveness internal control PT. Langen Kridha Pratyangga Sumedang. 


\section{Research Method and Data Analysis}

\section{Research Method}

The object of this research is the influence of accounting information system on the effectiveness of internal control at PT. Langen Kridha Pratyangga, Tbk. The company is located at Jalan Raya Jatinangor Km. 20 Bandung, Sumedang, West Java and was established in Bandung on March 6, 1986. In the course of conducting its business, the company has built Golf Course and Club House facilities which have other supporting facilities like lodging, tennis court, swimming pool, restaurant, children's play area and out bound.

This research is a quantitative research using observation of respondents that have been defined. One kind of qualitative research is observation, a method that not only observing participants, this research also covered with ethnography and research work in the field. In the observational research design, several study sites are involved. Observational data could be integrated into confirmatory research [9]. Researchers ought to test the hypothesis that it can be concluded about the influence between the variables previously defined.

This research using primary data obtained by distributing questionnaires to the respondents and taken directly without going through intermediaries. Primary data is generated from a survey based on a questionnaire that had been used beforehand. Data are collected by distributing questionnaires to the respondents working for the PT. Langen Kridha Pratyangga Sumedang. The questionnaires were distributed directly to the respondent so that it can be ascertained and filled in by the respondents.

The population of this research is PT. Langen Kridha Pratyangga Sumedang, and the entire population is used as a sample for this study using survey method. Survey method is commonly referred to as purposive sample. This is often determined when the number of relatively small populations, or research to make generalizations with a very small error.

The purposive sampling technique used in this research, a sampling technique that collected population by certain criteria. The criteria used can be based on the consideration of specific (judgment) or a ratio (quota) [17].

Based on data collected from PT. Langen Kridha Pratyangga Annual Report the company has 238 employees.

Table 1. List Employee of PT Langen Kridha Pratyangga Sumedang

\begin{tabular}{llc}
\hline No. & \multicolumn{1}{c}{ Position } & Amount \\
\hline 1. & General Manager & 1 \\
2. & Manager & 2 \\
3. & Supervisor \& Assistant & 27
\end{tabular}

\begin{tabular}{llc}
4. & Staff & 208 \\
\hline Total & & $\mathbf{2 3 8}$ \\
\hline Source: & $\begin{array}{l}\text { PT. Langen } \\
\text { Sumedang Annual Report Year of } \\
\\
2014\end{array}$
\end{tabular}

To determine sample of population, the Slovin formulation [32] used is as follows:

$$
\begin{aligned}
\mathrm{N} & \geq \frac{238}{1+\left\{238 .(0.1)^{2}\right\}} \\
& \geq 70.4142011843 \\
& \approx 70 \text { respondents }
\end{aligned}
$$

\section{Operational Definition}

Independent variables used in this research is AIS. AIS is a structure blending in an entity, which uses physical resources and other components to change the financial/accounting transaction data into accounting information with the purpose to meet the need for information from the user or the users. Subvariable in this reseach include procedure and instruction, people, data, software, information technology infrastructure [27]. Human resources in this reseach means capability employee to do their work and collaborate with implementing AIS. Procedure and instructions are set of company policy to lead work according to its purpose. Data used in AIS is an information that used to carry out the activities of an entity and to provide information for internal and external parties that have necessaries. Software is intangible aids that make it easier for someone to work. Information technology infrastructure is a set of components required to operate and manage company in IT environments.

Meanwhile dependent variable used in this research are the effectiveness of internal control at PT. Langen Kridha Pratyangga Sumedang. Internal control is a process to obtain sufficient confidence about the achievement of the objectives in terms of the following: the reliability of financial reporting, compliance with laws, rules, and regulations in force, the effectiveness and efficiency of operations [24]. So, nternal control effectiviness is how to maintain a organization goals through efficient and effective.

\section{Determination of Scores}

The scale used in this research is the Likert scale of 1-5. Likert scale is used to measure the response or the response someone about social objects [29]. Every answer is associated with the form of a question or supports the stance as follows:

1. Answer strongly agree/very often/very high is given score 5

2. Answer agree/often/high is given score 4

3. Answer undecided/sometimes is given score 3 
4. Answer disagree/rarely/low are given score 2

5. Answer strongly disagree/never at all/very low is given score 1

\section{Data Analysis Technique}

The quality of data in this reseach measured with validity test and reliability test. Meanwhile, data analysis technique in this research is determined by using multiple regression analysis techniques. Mutiple regression analysis include normality, multicollinearity, heterocedasity [10]. Multiple linear regression analysis use in this study because so this research can directly measure the influence between more than one variable (the independent variable) on variable (the dependent variable). Formulation Regression Model Regression model used is:

$$
Y=\alpha+\beta_{1} X_{1}+\beta_{2} X_{2}+\beta_{3} X_{3}+\beta_{4} X_{4}+\beta_{5} X_{5}
$$

Description:

$$
\begin{aligned}
& Y=\text { internal control } \\
& \alpha=\text { constants } \\
& \beta=\text { regression coefficients } \\
& \mathrm{X}_{1}=\text { people/human resources } \\
& \mathrm{X}_{2}=\text { procedures and instructions } \\
& \mathrm{X}_{3}=\text { data } \\
& \mathrm{X}_{4}=\text { software } \\
& \mathrm{X}_{5}=\text { information technology infrastructure }
\end{aligned}
$$

Hypothesis testing in this study is conducted using (1) Partial Test ( $t$ test), (2) Simultaneous Test (F test) and Coefficient of Determination $\mathrm{R}^{2}$.

\section{Result and Discussion}

\section{Respondent Background}

Age is one of the factors that influences the success of an activity and will also affect the physical ability to work and ways of thinking. Overview the age of respondents with total are 70 people, consists of 21-30 years old are 28 people, 31-40 years old are 22 people, and 42-50 years old are 22 people. The respondent by sex characteristic are 31 respondents are man and 39 respondents are woman. So characteristic responden by education consist of 34 respondent from high school, 18 respondent from diploma, and from bachelor degree are 18 respondent. Based on the work period, the majority of respondents have been working for $>10$ years $(41.42 \%)$. Followed by 26 people have been working for 1-5 years $(37.14 \%)$ and 15 people have been working 5-10 years $(21.42 \%)$.

\section{Validity Test}

Validity test are done to test item of variable on people or human resources, procedures and instructions, based on data, using software, information technology infrastructure, and internal control variable. In pilot test, the value of $r_{\text {table }}$ is with $\mathrm{N}=20$ and $5 \%$ of significance level 0.444 . Based on the table, it turns out there is a question item which the value is below 0.444 . So, it cannot be used as question in research instrument. Another question item which the value is above 0.444 can be used as a research instrument because it is declared valid.

There are three questions in variable people/ human resources, three questions in variable procedures and instructions, three question in variable data, three questions in software variable, three questions in technology infrastructure variable, that have proven to be invalid in from questions of test result. This happen because of the correlation value is less than the critical value at the level of significance of $95 \%$, so that those three questions cannot be used as an instrument of research.

\section{Reliability Test}

4.1 Table 2. Reliability Test

\begin{tabular}{llcl}
\hline Item & $\begin{array}{c}\text { Coefficient } \\
\text { Cronbach } \\
\text { Alpha }\end{array}$ & $\begin{array}{c}\mathrm{R} \\
\text { table }\end{array}$ & Information \\
\hline 1 & 0.817 & 0.450 & Reliable \\
2 & 0.613 & 0.450 & Reliable \\
3 & 0.783 & 0.450 & Reliable \\
4 & 0.742 & 0.450 & Reliable \\
5 & 0.870 & 0.450 & Reliable \\
6 & 0.687 & 0.450 & Reliable \\
\hline
\end{tabular}

Sources: Processed primary data

Based on the reliability test that show in Table 2, the independent variable people/human resources retrieve the value of the alpha $(\alpha)$ shows 0.817 , procedures and instructions shows 0.613 , data shows 0.783, software shows 0.742 , and information technology infrastructure show 0.870 . Likewise, the dependent variable reliability test of internal control retrieves the value of the alpha $(\alpha)$ of 0.687 . Those crobatch alpha value above $r_{\text {table }}$ of 0.450 . Based on Ghozali (2006) criterion, it means instrument construct for each independent variables and dependent variable are reliable to use because they show values above value 0.450 of $r_{\text {table }}$.

\section{Classical Assumption Test}

a. Normality Test

Table 3. Two-way Kolmogorov-Smirnov Test Results

\begin{tabular}{lll}
\hline $\begin{array}{l}\text { Asymp.Sig } \\
\text { (2-tailed) }\end{array}$ & $\begin{array}{l}\text { Kolmogorov } \\
\text { Smirnov } \\
\text { statistic }\end{array}$ & Information \\
\hline 0.284 & 0.987 & $\begin{array}{l}\text { Normal } \\
\text { Distribution }\end{array}$ \\
\hline
\end{tabular}




\section{Sources: Processed primary data}

Based on Table 3, it shows that the value of Asymp.Sig (2-tailed) of 0.284 and above the significant value of 0.05 . In other words, the residual variable has normal distribution, so the research is feasible to proceed.

b. Multicollinearity Test

Table 4. Multicollinearity Test Results

\begin{tabular}{lll}
\hline Variable & Tolerance & VIF \\
\hline $\begin{array}{l}\text { People/Human } \\
\text { Resources }\end{array}$ & 0.654 & 1.529 \\
$\begin{array}{l}\text { Procedures and } \\
\text { Infrastructure }\end{array}$ & 0.329 & 3.043 \\
$\begin{array}{l}\text { Data } \\
\text { Software }\end{array}$ & 0.431 & 2.321 \\
Information & 0.569 & 1.757 \\
Technology & 0.471 & 2.122 \\
Infrastructure & & \\
\hline
\end{tabular}

Sources: Processed primary data

The table shows that all the tolerance value of each variable over 0.10 and VIF is below 10 . So, that means there is no multicollinearity in a multiple regression because VIF value $<0.10$ [10].

\section{c. Heteroscedasticity Test}

When the results show significant value, that means heteroscedasticity occurred [10]. The following table shows Park Glejser test results:

Table 5. Heteroscedasticity Test Results

\begin{tabular}{lll}
\hline \multicolumn{1}{c}{ Variable } & \multicolumn{1}{c}{ T } \\
& Statistics & Significant \\
\hline $\begin{array}{l}\text { People/Human } \\
\text { Resources }\end{array}$ & -0.990 & 0.326 \\
$\begin{array}{l}\text { Procedures and } \\
\text { Instruction }\end{array}$ & -1.455 & 0.151 \\
$\begin{array}{l}\text { Data } \\
\text { Software }\end{array}$ & 0.611 & 0.543 \\
$\begin{array}{l}\text { Information } \\
\text { Technology }\end{array}$ & -0.071 & 0.943 \\
Infrastructure & & 0.165 \\
Sources: Processed primary data & \\
\hline
\end{tabular}

The table above shows that all independent variables are not significantly influencing the dependent variable, where the level of significance of each independent variable is greater than $5 \%$. Thus, the conclusion is no heteroscedasticity in the regression equation.

\section{Results of Multiple Regression Analysis and Hypotheses Testing}

Table 6. Results of Multiple Regression Analysis Calculation

\begin{tabular}{|c|c|c|c|}
\hline No. & Variable & $\begin{array}{l}\text { Regression } \\
\text { Coefficients }\end{array}$ & Significant \\
\hline 1. & Constants & 0.513 & \\
\hline 2. & $\begin{array}{l}\text { People/Human } \\
\text { Resources }\end{array}$ & 0.064 & 0.534 \\
\hline 3. & $\begin{array}{l}\text { Procedures and } \\
\text { Instruction }\end{array}$ & 0.265 & 0.018 \\
\hline 4. & Data & 0.227 & 0.019 \\
\hline 5. & Software & 0.187 & 0.012 \\
\hline 6. & $\begin{array}{l}\text { Information } \\
\text { Technology } \\
\text { Infrastructure }\end{array}$ & 0.320 & 0.001 \\
\hline \multicolumn{4}{|c|}{ Adjusted $R^{2}=0.741$} \\
\hline \multicolumn{4}{|c|}{ F table $=2.37$} \\
\hline \multicolumn{4}{|c|}{ F statistic $=40.394$} \\
\hline
\end{tabular}

The regression equation above is worth the constant of 0.513 , it means that the accounting information system is 0.513 when other variables are constant. The variable regression coefficient value of people/human resources is 0.064 . The higher the coefficient value of people/human resources quality, it means the higher company's internal control system quality.

The coefficient of regression procedures and instructions is 0.265 . The higher the coefficient value of procedures and instructions, it means the higher company's internal control system quality.

The coefficient of regression data variable is 0.227 . The higher the coefficient value of data, it means the higher company's internal control system quality.

The coefficient of regression software variable is 0.187 . The higher the coefficient value of software, it means the higher company's internal control system quality.

The coefficient of regression information technology infrastructure is 0.320 . The higher the coefficient value of information technology infrastructure, it means the higher company's internal control system quality.

Based on the results of the regression equation above, R2 value is 0.741 or $74.1 \%$. The figure shows that the accounting information system can be explained by the variables of people/human resources, procedures and instructions, data, software, and information technology infrastructure for about $74.1 \%$ and other variables which are not studied is $25.9 \%$. 


\section{Goodness of Fit Analysis}

Based on Table 4.9, $\mathrm{F}_{\text {statistic }}$ is 40.394 with the significance of 0.000 . With the degree of freedom $(\mathrm{k}-1),(\mathrm{n}-\mathrm{k})$ is $(6-1),(70-6)$, the $\mathrm{F}_{\text {table }}$ value is 2.37 . Therefore, $F_{\text {statistic }}$ is greater than $\mathrm{F}_{\text {table }}$ with $40.394>$ 2.37 and the significance is $0.000<0.05$. It can be inferred that the regression model is feasible.

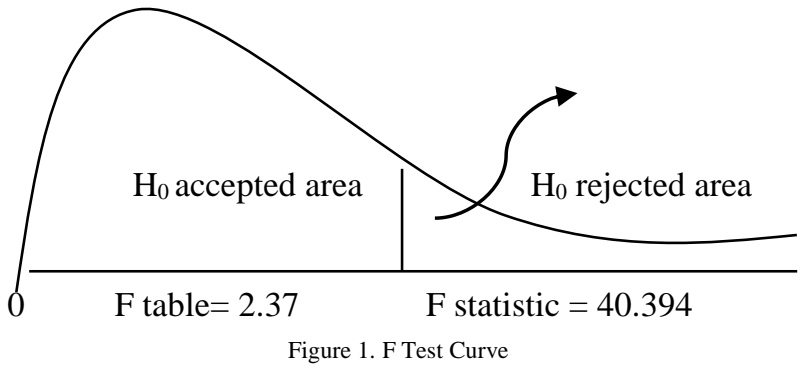

Hypothesis Testing Result and Discussion

Table 7. Hypothesis Test Results Summary

\begin{tabular}{lllll}
\hline No. & Variable & Significant & $\mathbf{T}_{\text {statistic }}$ & $\mathbf{T}$ table \\
\hline 1. & $\begin{array}{l}\text { People/Human } \\
\text { Resources } \\
\text { 2. }\end{array}$ & 0.534 & 0.626 & 2.38081 \\
& $\begin{array}{l}\text { Procedures and } \\
\text { Instruction }\end{array}$ & 0.018 & 2.425 & 2.38081 \\
3. & Data & 0.019 & 2.406 & 2.38081 \\
4. & Software & 0.012 & 2.592 & 2.38081 \\
5. & $\begin{array}{l}\text { Information } \\
\text { Technology }\end{array}$ & 0.001 & 3.602 & 2.38081 \\
\multicolumn{4}{l}{ Infrastructure } \\
Sources: Processed Primary Data & & \\
\hline
\end{tabular}

\section{a. Hypothesis 1}

Based on a 95 percent confidence level $(\alpha$ $=0.05)$ and the degree of freedom $(\mathrm{df})=(\mathrm{k}-1)$ $(\mathrm{n}-\mathrm{k})$, the value of $\mathrm{t}_{\text {table }}$ is 2.37 . The first hypothesis testing results indicate that the effect of people/human resources variable on internal control system have significant value of 0.534 and 0.626 . The significance value is 0.05 and $a t_{\text {statistic }}<\mathrm{t}_{\text {table }}(0.626<2.38081)$, meaning that the statement in the first hypothesis is supported by this study. Thus, the people/human resource variable has no influence on internal control system. So the first hypothesis is not supported.

The results of this research not supported previous research which found the accounting competency is an important element of the dynamic AIS capability for copany internal control [26]. Basically, employees running the accounting information systems procedures without realizing such employee is an individual part of the system itself. This is because employees feel a lack of outreach done by the company. Personnel policy participation influences the company's ability to hire employees who are quite capable to accomplish company goals. This policy outlines how companies hire, train, evaluate, promote, and provide rewards on employees. Finally, the effectiveness on the internal control structure relies on the honesty and the ability of employees. The small possibility of honest employees will do the defalcation and the small possibility of employees to make mistakes. It can be concluded that the assumption of the probability of collusion between two or more persons would be low in an enterprise which formally planned is true. For someone, estimating the irregularities of others and apparently incorrect will cause prevention costs to that person. The employee must be replaced by other employees and lost his job or receive other punishment.

\section{b. Hypothesis 2}

Based on a 95 percent confidence level $(\alpha$ $=0.05)$, and the degree of freedom $(\mathrm{df})=(\mathrm{k}-1)$ $(\mathrm{n}-\mathrm{k})$, the value table is 2.37 . The second hypothesis testing results indicate that the effect of procedures and instructions variable on internal control system have significant value of 0.018 and 2.425 . The significance value is $\leq 0.05$ and $t_{\text {statistic }}>t_{\text {table }}(2.425>$ 2.38081 ), meaning that the statement in the second hypothesis is supported by this study. Thus, the procedures and instructions variable have positive influence on internal control system. Thus, the second hypothesis is supported.

The results of this research show that the higher the quality of the procedures and instructions, then the higher effectiveness of the internal control system. [20] found there is a significant and positive influence of the quality of the procedures and instructions on the effectiveness of the internal control system. The quality of the internal control is considered effective if each function or part that authorizes the activity of the company. The authorization limits the transaction activity or performances only on the selected person. Authorization of transactions and activities prevents activity that is not authorized. In fact, authorization management may be general or particular. Particular authorization is conducted on those individual transactions.

Separation functions are required to reduce the possibility of confusion and irregularities. Separation functions are implemented by giving responsibility for authorizing transactions, recording transactions, and handling physical assets to 
different people conducted by separate functions. The access to assets is only allowed in relevance with the authorization by management. This obligation is to control and secure physical assets and the use of assets, such as a safe facility and authorization to access computer programs and document data. Physical theft and damage are a substantial treatment on a company. Physical restraint is directed at the reduction of physical theft and damage.

\section{c. Hypothesis 3}

Based on a 95 percent confidence level $(\alpha$ $=0.05)$, and the degree of freedom $(\mathrm{df})=(\mathrm{k}-1)$ $(\mathrm{n}-\mathrm{k})$, the value table is 2.37 . The third hypothesis testing results indicate that the effect of data variable on internal control system have significant value of 0.019 and 2.406. The significance value is $\leq 0.05$ and tstatistic > ttable $(2.406>2.38081)$, meaning that the statement in the third hypothesis is supported by this study. Thus, the data variable has positive influence on internal control system. Thus, the third hypothesis is supported.

The results of this study show that the higher the quality of the data collected, then the higher effectiveness of the internal control. This reseach in line with [3] and [33]. The collected data are related to record on the journal of transaction. AIS used in terms of control of transaction to prevent and detect errors as well as threats on the system. AIS provide journalizes the economic activity in the form of accounting transaction, summarizing, and report. In addition, the system will process the accounting transaction. Then, the AIS produces a variety of documents and reports. The terms of this arises from a business activity cycle outlines of how accounting activities operate.

\section{d. Hypothesis 4}

Based on a 95 percent confidence level $(\alpha$ $=0.05)$, and the degree of freedom $(\mathrm{df})=(\mathrm{k}-1)$ $(\mathrm{n}-\mathrm{k})$, the value table is 2.37. The fourth hypothesis testing results show that the software variable gives influence on internal control system have significant value of 0.012 and 2.592. The significance value is $\leq 0.05$ and $\mathrm{t}_{\text {statistic }}>\mathrm{t}_{\text {table }}(2.592>2.38081)$, meaning that the statement in the fourth hypothesis is supported by this study. Thus, the software variable has positive influence on internal control system. Thus, the fourth hypothesis is supported. The results of this research show that the higher the quality of the software then the higher effectiveness on the internal control.
In accordance with [15], the internal control system is influenced by end user accounting software. In this context, accounting software is made ease of use and advanced data processing. It also said in [8].

Based on the results of the research, PT. Langen Kridha Pratyangga has used Microsoft Excel 2010 software formulas which have been modified in accordance with the needs of the company. The company is aware that any company's activity involving both internal and external accounting software, especially, accounting department personnel. Accounting department personnel in the company has the task to manage expenses and revenues that come out every day. The manually record is not a good move to achieve effectiveness. Using accounting software was a good decision to keep in order remaining productive. The use of the integrated accounting software is considered appropriate because it reduces the error caused by employees and reduces fraud. The integrated accounting software allows providing preventative measures. So that it could detect any cheating and other actions that do not comply with company policies. Integrated software means all transactions input by software can be seen by anyone, no exception all elements of the company. The data entry changes suddenly and not natural can be directly known. So that it maintains the quality of internal control systems of PT. Langen Kridha Pratyanga Sumedang.

\section{e. Hypothesis 5}

Based on a 95 percent confidence level ( $\alpha$ $=0.05)$, and the degree of freedom $(\mathrm{df})=(\mathrm{k}-1)$ $(\mathrm{n}-\mathrm{k})$, the value table is 2.37. The fifth hypothesis testing results indicate that the effect of information technology infrastructure variable on internal control system have value of 0.01 and 3.602. The significance value is $\leq$ 0.05 and $t_{\text {statistic }}>t_{\text {table }}(3.602>2.38081)$, meaning that the statements in the fifth hypothesis is supported by this study. Thus the variable information technology infrastructure has positive influence on internal control system, and the fifth hypothesis is supported.

The results of this study show that the higher the quality of the information technology infrastructure, the higher effectiveness on the internal control. [34] found there is a significant and positive influence on the quality of the information technology infrastructure on the effectiveness of the internal control system. Information technology infrastructure is in the form of a convenient work space facilitated by working 
equipment and kept supporting environmental work unit.

The term of accounting information systems include the utilization of information technology to provide information for the users. Computers are used in all types of information systems. Information technology includes computers and other technologies used to process information. The company uses computers to process data transactions have the function of information systems. The functions of the information systems are responsible for data processing. Data processing in accounting information system application is the most fundamental in any organization. The function of information system has evolved from a simple organizational structure that includes several people to a complex structure that includes a lot of specialist quality.

Office automation is a general term that describes the utilization of information technology in the office. Office automation system consists of electronic technology that allows processing a variety of messages and documents. Office Automation increases productivity by way of reducing the time and cost of processing of business communications. The company has implemented the information technology that supports the presence of accounting information systems that includes document image system and quick response system [31].

\section{Conclusion and Implication}

This research aims to analyze the influence of accounting information system on the effectiveness of internal control at PT. Langen Kridha Pratyangga Sumedang. Based on the research result and discussion, variable of procedures and instructions, data, software, and information technology infrastructure partialy have significant and positive influence on effectiveness of internal control in PT. Langen Kridha Pratyangga Sumedang. Meanwhile, people/human resources have no influence on effectiveness of internal control in PT. Langen Kridha Pratyangga Sumedang.

Based on the above conclusions of the research, it is recommended that the company assessed the qualification of the resources are still below the standard. This is due to the capabilities and the needs of company employees are not as expected. The company is attempting not to request the petition against employee. However, they need to do training and coaching that takes time. It costs internal control system to be ineffective and inefficient. Second, he effectiveness of the internal controls is influenced by the procedures and instructions that are designed by the company. The employees work depend on Standard Operational Procedure (SOP). The company has a control in accordance with the SOP. Third, the qualification of the human resources influences the low process data directly. A lot of work doesn't match results and inefficient, it seems like a wasting time and paper for printing many times. As a result, the supervisor has not found errors in published reports. Errors can be detected by the applied of an effective internal control system. Fourth, the company has been using Microsoft Excel 2010 software modified in such a way in accordance with the needs of the company. All of entire registered account transactions of companies are inputted in the system to make it easier for employees to the use software at the first time. Easy to use accounting software influences the timely accounting report. Fifth, the employee felt discomfort before the work environment salary increases for four times in the past 2 years affect the sustainability of the system of internal control. After the raising of salary, the whole procedure and the system can work effectively. Along with that, the local government has extended the contract of land use at the company for 30 years into the future.

This study also have limitation such the independent variables, i.e. people/human resources, procedures and instructions, data, software, and information technology infrastructure is only partially explain quarter and half of variables that may explain the dependent variables. So that there is still some other variable of research i.e. people/human resources, procedures and instructions, data, software, and information technology infrastructure which can be examined to explain the dependent variables such as type of data, the frequency of data, and level of education of users. Then, this study uses only samples of PT. Langen Kridha Pratyangga Sumedang's employees, so that the results obtained are not representative of the wider region. The method of data collection in this study is using questionnaires, so that there is a possibility of respondents may not be serious, dishonest, or misinterpretation in giving the answer. All of the question concerns the problem of accounting information systems so most employees are very carefully and tend to be secretive about the actual conditions.

\section{References}

A. Ajzen, I., 2005. Attitudes, Personality, and Behavior. Open University Press, New York.

B. B. Akbar, Jihad, Adam, M., 2014. BPK: Kasus Kelemahan Sistem Pengendalian Internal Masih Marak [WWW Document]. URL https://bisnis.news.viva.co.id/news/read/49669 2-bpk-kasus-kelemahan-sistem-penge ndalian- 
internal-masih-marak, accessed on 16th August 2015

C. C. AlQudah, H.M.A., Shukeri, S.N.B., 2014 The Role Of Data Quality And Internal Control In Raising The Effectiveness Of Ais In Jordan Companies. INTERNATIONAL JOURNAL OF SCIENTIFIC \& TECHNOLOGY RESEARCH 3, 298-303.

D. D. Azwar, S., 2007. Sikap Manusia Teori dan Pengukurannya. Pustaka Pelajar, Yogyakarta.

E. Bohlouli, M., Mittas, N., Kakarontzas, G., Theodosiou, T., Angelis, L., Fathi, M., 2016. Competence Assessment as an Expert System for Human Resource Management: A Mathematical Approach. Journal of Expert Systems with Applications. https:// doi.org/10.1016/j.eswa.2016.10.046

F. Cole, W.G., 2002. Sistem Akuntansi Zaki Baridwan (Penyusunan Prosedur dan Metode)., fifth. ed. Penerbit BPFE Universitas Gajah Mada, Yogyakarta.

G. D’Atri, A., M., D.M., Casalino, N., 2008. Interdisciplinary Aspects of Information Systems Studies. Physica-Verlag, Springer, Germany 1-416. https://doi.org/10.1007/ 9783-7908-2010-2 ISBN 978-3-7908-2009-6

H. Granlund, M., 2011. Extending AIS research to management accounting and control issues: A research note. International Journal of Accounting Information Systems 12, 3-11.

I. Gray, D., 2009. Doing Research in the Real World. Sage Publications, California.

J. Gujarati, D., Porter, D.., 2009. Basic Econometrics, fifth edit. ed. McGraw-Hill, New York.

K. Guo, J., Huang, P., Zhang, Y., Zhou, N., 2016. The Effect of Employee Treatment Policies on Internal Control Weaknesses and Financial Restatements. American Accounting Association 91.

L. Hall, J.A., 2011. Accounting Information System, 7th ed. South-Western Cengage Learning, United States of America.

M. Hall, J.A., 2001. Accounting Information System, fourth. bo. ed. Salemba Empat, Jakarta.
N. Indralesmana, K.W., Suaryana I.G.N.A., 2014. Penerapan Sistem Informasi Akuntansi Dan Kinerja Individu Pada Usaha Kecil Dan Menengah Di Nusa Penida. E-Jurnal Akuntansi Universitas Udayana 7.

O. Istianingsih, Wijanto, S.H., 2008. Pengaruh Kualitas Sistem Informasi, Perceived Usefulness dan Kualitas Informasi Terhadap Kepuasan Pengguna Akhir Software Akuntansi. Simposium Nasional Akuntansi XI.

P. Janson, M.A., Subramanian, A., 1996. Packaged Software:Selection and Implementation Policies. INFOR 34(2), 133151.

Q. Jogiyanto, 2001. Analisis \& Desain Sistem Informasi: Pendekatan Terstruktur Teori dan Praktek Aplikasi Bisnis. Andi, Yogyakarta.

R. Krismiaji, 2002. Sistem Informasi Akuntansi. YKPN Yogyakarta, Yogyakarta.

S. La Midjan, A., Azhar, S., 2001. Sistem Informasi Akuntansi I dan II. Lembaga Informatika, Bandung.

T. Marzuki, A., 2012. Analisis Hubungan Sistem Informasi Akuntansi Penjualan dengan Efektifitas Pengendalian Internal Penjualan pada Perusahaan Garment di Tanjungpinang. Universitas Maritim Raja Ali Haji Tanjungpinang.

U. McLeod, R.J., 2001. Sistem Informasi Manajemen. Prenhallindo, Jakarta.

V. Messier, W.F., Glover, S.M., Prawitt, D.F., 2005. Auditing \& Assurance Services a Systematic Approach, 4th ed. Salemba Empat, Jakarta.

W. Muda, I., Wardani, D.Y., Erlina, Maksum, A., Lubis, A.F., Bukit, R., Bakar, E.A., 2017. The Influence of Human Resources Competency and The Use Of Information Technology On The Quality Of Local Government Financial Report with Regional Accounting System as An Intervening. Journal of Theoretical and Applied Information Technology 95.

X. Mulyadi, 2012. Auditing. Salemba Empat, Jakarta.

Y. Ompusungu, H., 2002. Pengaruh Penerapan Sistem Informasi Akuntansi terhadap Efektifitas Pengendalian Intern. Jurnal Ilmiah 
Akuntansi 1.

Z. Prasad, A., Green, P., 2015. Organizational Competencies and DynamicAccounting Information System Capability:Impact on AIS Processes and FirmPerformance. Journal of Information Systems 29, 123-149.

AA. Romney, M.B., 2013. Sistem Informasi Akuntansi edisi 13, Salemba Empat.

BB. Saeidi, H., Prasad, B., 2014. Impact of Accounting Information Systems (AIS) on Organizational Performance: A case Study of TATA Consultancy Services (TCS) - India. UCT Journal of Management and Accounting Studies 3.

CC. Suliyanto, 2011. Ekonometrika Terapan: Teori dan Aplikasi dengan SPSS. Penerbit ANDI, Yogyakarta.

DD. Suryandi, D., 2011. Promosi Efektif
Menggugah Minat \& Loyalitas Pelanggan. Oryza, Jakarta.

EE. Sutabri, T., 2007. Sistem Informasi Manajemen. ANDI, Yogyakarta.

FF. Umar, H., 2007. Metode Penelitian dan Aplikasi dalam Pemasaran. Gramedia Pustaka Umum, Jakarta.

GG. Wang, Z., 2014. An Entropy Testing Model Research on the Quality of Internal Control and Accounting Conservatism: Empirical Evidence from the Financial Companies of China from 2007 to 2011. Hindawi Publishing Corporation Mathematical Problems in Engineering 2014.

HH. Yosefrinaldi, 2010. Pengaruh Kapasitas Sumber Daya Manusia dan Pemanfaatan Teknologi Informasi terhadap Kualitas Laporan Keuangan Pemerintah Daerah dengan Variabel Intervening Sistem Pengendalian Intern Pemerintah. Universitas Negeri Padang. 